\title{
Synergistic Antinociceptive, Anti-inflammatory Interaction between Vitamin B12 and Ketorolac in Long Evans Rats
}

\author{
Md. Mizanur Rahman, Noorzahan Begum, Mahadi Abdur Rouf, and Shahriar Masood
}

\section{ABSTRACT}

In certain painful disorders, B12 vitamins have been documented to be clinically useful alone or paired with non-steroidal anti-inflammatory drugs (NSAIDs). However, it has not been identified to equate these effects with related effects of ketorolac tromethamine (KT) and their combination. To test and compare the effects of vitamin B12 on pain with those of the combination of vitamin $\mathrm{B} 12$ with $\mathrm{KT}$ in rat models. This experimental research was performed at the Department of Physiology, BSMMU. The control (A, A1 with $5 \mathrm{ml} / \mathrm{kg}$ normal saline) and experimental (B1, B1a with $15 \mathrm{mg} / \mathrm{kg} \mathrm{B12}$; B2, B2a with $10 \mathrm{mg} / \mathrm{kg} \mathrm{KT}$; B3, B3a with B12+KT) groups of 5 rats in each group were divided into 40 (forty) long Evans rats (215 \pm 35 gm) of either sex. Both medications and vitamins were administered intraperitoneally in a single dose just one hour prior to the writhing and paw edema test caused by formalin. The statistical study was carried out by ANOVA, followed by the post-hoc Bonferroni test. In the interpretation of outcomes, $\mathbf{p} \leq \mathbf{0 . 0 5}$ was regarded as significant. B12 lowered only the writhing count and KT lowered both writhing appearance latency time and writhing count significantly $(\mathbf{p} \leq \mathbf{0 . 0 0 1})$ in the writhing test. However, the combination of $B 12$ and $K T$ significantly $(p \leq 0.001)$ lowered both the study variables in the writhing test. In addition, KT lowered edema volume significantly $(p \leq 0.01)$ in the paw edema test. The combination of $B 12$ and $K T$, on the other hand, substantially $(p \leq 0.001)$ decreased the amount of edema in the paw edema test. It can be concluded that vitamin B12 has analgesic and anti-inflammatory effects, and that the combination of B12 with KT is more effective than when administered individually.

Keywords: Pain, vitamin B12, Ketorolac, paw edema test, formalin test.
Published Online: July 09, 2021

ISSN: $2736-5476$

DOI: 10.24018/ejclinicmed.2021.2.3.94

Md. Mizanur Rahman*

Department of Physiology, Enam Medical College \& Hospital, Savar, Dhaka, Bangladesh.

(e-mail: mizandr001@gmail.com)

Noorzahan Begum

Department of Physiology, Bangabandhu Sheikh Mujib Medical University (BSMMU), Dhaka, Bangladesh.

(e-mail: noorzahan52@gmail.com )

Mahadi Abdur Rouf

Department of Physiology, Northern

International Medical College, Dhaka, Bangladesh.

(e-mail: mail.mahadi@gmail.com )

Shahriar Masood

Department of Physiology, Jahurul Islam Medical College, Bajitpur, Kishoregonj, Bangladesh.

(e-mail: shahriarmasood@ gmail.com)

*Corresponding Author

\section{INTRODUCTION, BACKGROUND AND OBJECTIVES}

Nociception is an enormous field in both neuroscience and medical research, as is pain [1]. The severity of pain does not coincide with the degree of tissue damage, and it affects one's standard of living if it does not manage properly. Pain associated with acute injury to tissue, illness or intervention can be seen as a symptom and is an active symptom in many medical conditions [2]. In addition, nociceptive pain, however, is a crucial physiological sensation triggered by peripheral nerve fibre stimulation. Nociceptors have characteristic sensitivity or thresholds [3]. Thus, it is a central early warning mechanism for tissue damage [4] [5]. It may define as "Pain in the peripheral tissue caused by injury activating the nociceptors" [6]. Therefore, pain assessment is vital to find out the severity of the illness. It is also indispensable for an appropriate analgesic to chose. Twisting is another legitimate tool for assessing nociceptive and inflammatory pain behaviours in the animal model and is susceptible to different analgesic drugs. In this experiment, the writhing reaction consists of the contraction of the abdominal muscles and stretching the hind limbs together. This test is responsive to both opioids and non-opioid analgesics [7].

Moreover, a basic approach is the formalin-induced paw oedema test, among the numerous methods for measuring inflammation in animals. In this examination, subcutaneous formalin administration in any paw causes local tissue injury and paw oedema subsequently [8]. Ketorolac tromethamine (KT) is one of the most potent non-steroidal antiinflammatory drugs (NSAIDs) used in the treatment of inflammatory pain such as postoperative pain, renal colic, inflammation, lumbago, headache and cancer [9], [10]. Vitamins are perfect cost-effective alternatives, of which eight distinct water-soluble compounds make the vitamin B complex. In some animal studies, among these eight vitamins, supplementation with B12 in combination with B1 and B6 showed a decrease in nociceptive and inflammatory pain [11]-[15]. However, a single dose of $10 \mathrm{mg} / \mathrm{kg} \mathrm{KT}$ has been a sub-effective dose against nociceptive and inflammatory pain [16]. Combined administration of B vitamins (B1, B6, B12) with KT has also suggested potentiating nociceptive and inflammatory pain effects [15]. So far, however, the data on this matter is not adequate to draw any conclusion. Furthermore, no recorded data were available to compare the combined analgesic effects of vitamin B12 with $\mathrm{KT}$ on 
nociceptive and inflammatory pain with that of their administration. In this context, this study would have planned to assess the analgesic and anti-inflammatory effects of a single administration of Ketorolac and its combination with vitamin B12 to compare the combined analgesic and antiinflammatory effects of a single administration Ketorolac with those of individual administration in Long Evans rats.

\section{MATERIAL AND METHODS}

\section{A. Study Design}

This experiment was performed between March 2015 and February 2016 in the Pain Laboratory, Department of Physiology, Bangabandhu Sheikh Mujib Medical University (BSMMU), Dhaka.

\section{B. Procurement and Maintenance of Animals}

Forty (40) stable adult Long Evans rats of either sex, weighing 180 to $250 \mathrm{gm}$ [17], were acquired from the animal house at the University of Health Sciences Bangladesh (BUHS), Dhaka. We kept all the rats in the Department of Physiology's Pain Laboratory, BSMMU, where they were housed in specially designed plastic cages with six rats per cage under a light/dark cycle of 12/12 hours [7], [18]. The ambient room temperature, corresponding to the thermoneutral zone for rodents, was maintained at about 27 to $28^{\circ} \mathrm{C}$ [11]. Both rats had access to standard laboratory food and cooled boiled water [19]. They were retained there before the experiment for seven [7] consecutive days for environmental acclimatization. All the tests were carried out during the daytime between 08:00 and 16:00 to avoid circadian influences [20].

\section{Vitamins and Drugs Collection}

Vitamin B12 (Granules): Courtesy of Biopharma Pharmaceuticals Limited, Bangladesh.

Ketorolac Tromethamine (Granules): Courtesy of Novartis (Bangladesh) Limited.

Normal saline: Purchased from the local market (Popular infusions limited, Bangladesh).

Formalin: Purchased from the local market (MERCK, Germany).

Acetic acid: Purchased from the local market (MERCK, Germany).

Chloral Hydrate: Purchased from the local market (BDH Laboratory, Germany).

\section{Dose Schedule}

The granular vitamins B12 (Biopharma, Bangladesh) and Ketorolac tromethamine (Novartis, Bangladesh) were obtained and dissolved in standard saline $(5 \mathrm{ml} / \mathrm{kg}$ body weight). All the rats divided into control (A, A1) and experimental groups based on drugs and vitamin administration (B1, B1a; B2, B2a; B3, B3a). In addition, the control group (A, A1) received normal saline only $(5 \mathrm{ml} / \mathrm{kg}$ body weight) [20]. Vitamin treated group (B1, B1a) received vitamin B12 (15 mg/kg body weight) [21], ketorolac treated group (B2, B2a) received ketorolac tromethamine (KT) (10 mg/kg body weight) [22], combination-treated group (B3, B3a) received vitamin B12 (15 mg/kg body weight) and KT (10 mg/kg body weight) [21], [22] in equal quantities, respectively, to that of normal saline.

Just an hour after intraperitoneal [21], [23], [24] drug and vitamin administration, both rats underwent writhing and testing of formalin. All the rats were euthanized immediately after the above studies. Moreover, inflammation was assessed by the formalin-induced paw oedema test after sacrificing in groups A1, B1a, B2a and B3a.

\section{E. Writhing Test}

All the rats labelled for the writhing test put in the plexiglass observation chamber for 30 minutes daily for seven (7) consecutive days before the test to make the rats accustomed to the test environment. The rats marked for the twisting test were first put in a Plexiglas observation chamber on the day of the experiment and allowed to acclimatize for 30 minutes in the chamber environment. Then, following the investigation paradigm, they were injected intraperitoneally with regular saline or vitamin B12 or KT or combinations thereof. One hour later, using a 25-gauge syringe needle [7], [25], one $\mathrm{ml}$ of 2 per cent acetic acid was injected intraperitoneally [23], [25].

Immediately after injection, we counted 60 minutes of observation time for the latency of appearance of the first writhes and the number of writhes. Finally, the percentage of analgesic activity calculated using the formula below [26]:

$$
\begin{aligned}
& \% \text { Analgesic activity } \\
& =\frac{\text { Mean writhing count (control group }- \text { Treated group) }}{\text { Mean writhing count of control group }}
\end{aligned}
$$

The findings expressed as mean $\pm \mathrm{SEM}$, and the data were evaluated statistically by ANOVA, followed by the Bonferroni post hoc test. In the results, $p \leq 0.05$ accepted as the level of significance in the analysis of outcomes.

\section{F. Formalin Induced Paw Oedema Test}

All the rats were put in the observation chamber of the plexiglass formalin test box in pairs for fifteen minutes daily for four consecutive days and individually for three days before the test to make the rats accustomed to the test environment [27].

On the day of the experiment, following the experimental paradigm, all the rats were injected with normal saline, vitamin B12, KT or combinations thereof intraperitoneally. Only one hour later, a thick towel restrained the rat manually, and $50 \mu \mathrm{l}$ of dilute $(2.5 \%)$ formalin was injected subcutaneously with an insulin syringe into the plantar part of the right hind paw [27]-[29]. The animal was placed immediately afterwards in the observation chamber of the plexiglass formalin test box, and we observed pain behaviours for consecutive sixty minutes [24], [29]. We used a stopwatch to count the writhing. Every rat was anaesthetized with chloral hydrate $(400 \mathrm{mg} / \mathrm{kg}$ body weight, i.p.), and mortality was verified by decapitation after cessation of respiratory chest movement (30) — both the hind paws of the sacrificed rat of group A (control), B1 (vit. B12), B2 (KT) and B3 (B12+KT) were cut by sharp scissors at their knee joints, and a water plethysmometer was used to measure the volume of both hind paws. 
Paw volume $=$ water column height after paw immersionwater column height before paw immersion.

By subtracting the left paw volume from the right paw volume, the net volume of oedema was determined.

Net volume of oedema $=$ right paw volume-left paw volume [11].

\section{RESULTS}

\section{A. Antinociceptive Effects}

The results of a single dose of vitamin B12 and vitamin KT alone, as well as the combined administration of vitamin B12, vitamin $\mathrm{KT}$ in the acetic acid-induced writhing test, was observed, the pain behaviours were evaluated as the duration of latency time, and writhing counts.

The mean values of the duration of latency time were higher in all the study groups than those of the control group. However, this increment in latency time duration was statistically significant $(\mathrm{p} \leq 0.001)$ for rats with single KT administration and combined vitamin B12 and KT treatment in the writhing test (Table I \& Fig. 1).

TABLE 1: WRITHING APPEARANCE LATENCY TIME IN WRITHING TEST IN DIFFERENT GROUPS OF RATS $(\mathrm{N}=20)$

\begin{tabular}{ccc}
\hline Groups & $\mathrm{n}$ & $\begin{array}{c}\text { Latency time } \\
\text { (Minutes) }\end{array}$ \\
\hline A (control) & 5 & $5.4 \pm 0.50$ \\
B1 (vit. B12) & 5 & $6.9 \pm 0.29$ \\
B2 (KT) & 5 & $10.8 \pm 0.73$ \\
B3 (B12+KT) & 5 & $14 \pm 0.57$ \\
\hline
\end{tabular}

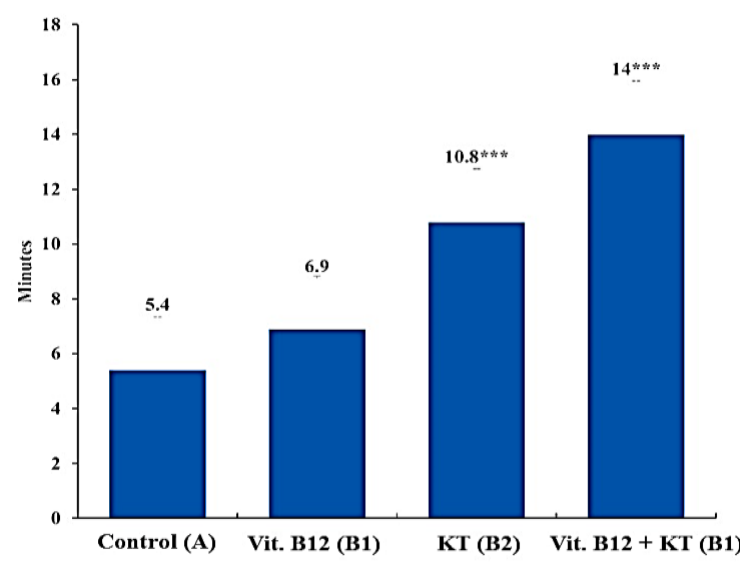

Fig. 1. Writhing appearance latency time in various groups of rats in the writhing test. For five rats, each bar represents the mean $\pm \mathrm{SE}$.

$* * *=\mathrm{p} \leq 0.001$ compared to those of control. $\mathrm{KT}=$ Tromethamine from Ketorolac.

TABLE II: WRITHING COUNTS IN WRITHING TEST IN DIFFERENT GROUPS OF RATS $(\mathrm{N}=20)$

\begin{tabular}{cccc}
\hline & & \multicolumn{2}{c}{ Number of writhes } \\
\cline { 3 - 4 } Groups & $\mathrm{n}$ & Frequency/60 min & $\begin{array}{c}\text { \% analgesic } \\
\text { activity }\end{array}$ \\
\hline A (control) & 5 & $74.6 \pm 2.42$ & ---- \\
B1 (vit. B12) & 5 & $59 \pm 1.81$ & 21.00 \\
B2 (KT) & 5 & $32 \pm 2.21$ & 57.10 \\
B3(B12+KT) & 5 & $26.40 \pm 1.16$ & 64.61 \\
\hline
\end{tabular}

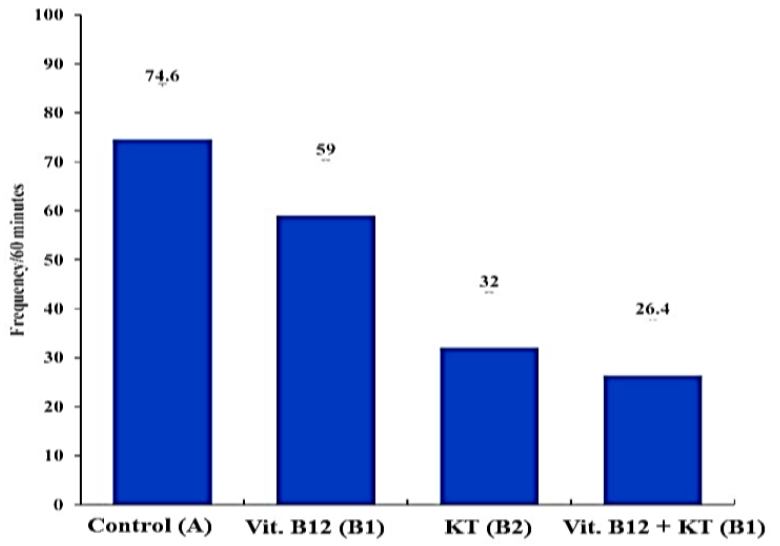

Fig. 2. Writhing counts in various groups of rats in the writhing test. For five rats, each bar represents the mean $\pm \mathrm{SE}$. $* * *=\mathrm{p} \leq 0.001$ compared to those of control. KT= Tromethamine from Ketorolac.

Similarly, the single administration of B12 and KT as well as the combined administration of vitamin B12 and KT in the writhing counts of the writhing test showed a substantial reduction in mean writhing values $(\mathrm{p} \leq 0.001)$ (Table II \& Fig. 2) compared to control.

In addition, the percentage of analgesic activity was higher in the combined treatment of vitamin B12 and KT (64.61\%) than in the single administration of B12 (21\%) and KT (57.10\%), respectively (Table II \& Fig. 4).

\section{B. Anti-inflammatory Effect}

The amount of oedema in the paw was measured at the end of the formalin test in this analysis. In all the study groups, the mean paw oedema volumes were lower than those of the control group. However, this decrease in rats treated with a single dose of KT $(\mathrm{p} \leq 0.01)$ was statistically significant. Moreover, in the combined B12 and KT $(\mathrm{p} \leq 0.001)$ treated group in the paw oedema examination, the paw oedema volume decreased further, statistically significant (Table II \& Fig. 5).

TABLE III: PAW OEDEMA VOLUME IN DIFFERENT GROUPS OF RATS (N=20)

\begin{tabular}{ccc}
\hline Groups & $\mathrm{n}$ & $\begin{array}{c}\text { Paw oedema volume } \\
\text { (ml of water) }\end{array}$ \\
\hline A1 (control) & 5 & $\mathbf{0 . 3 6} \pm \mathbf{0 . 0 2}$ \\
B1b (vit. B12) & 5 & $\mathbf{0 . 2 8} \pm \mathbf{0 . 0 2}$ \\
B2b (KT) & 5 & $\mathbf{0 . 2 0} \pm \mathbf{0 . 0 3}$ \\
B3b (B12+KT) & 5 & $\mathbf{0 . 1 6} \pm \mathbf{0 . 0 2}$ \\
\hline
\end{tabular}

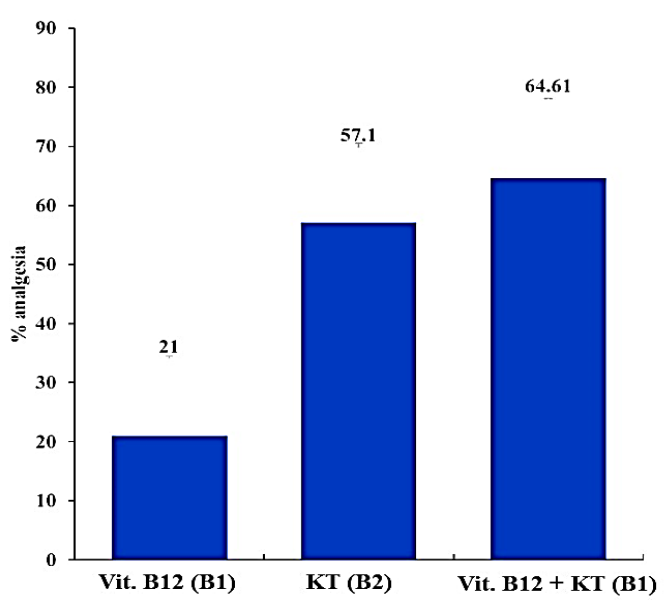

Fig. 4. Percentage $(\%)$ of analgesic activity in writhing test in different groups of rats. 


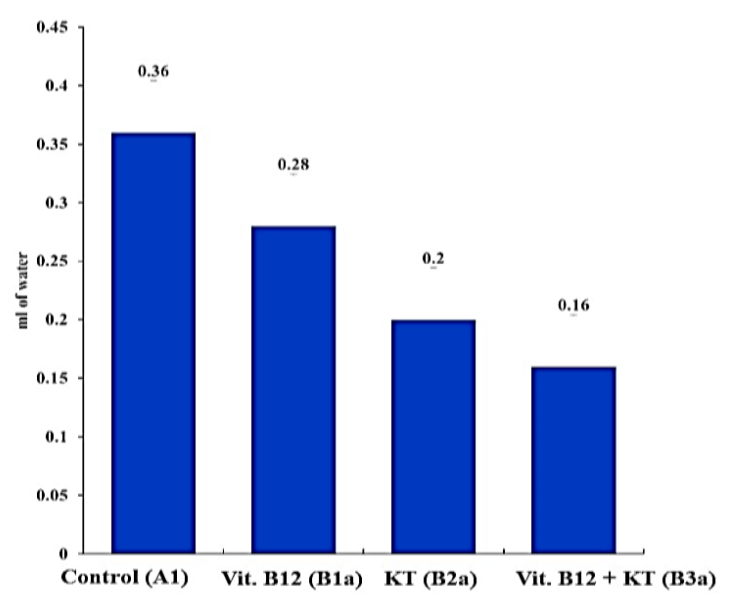

Fig. 5. Edema volume in various groups of rats in the paw oedema test. For five rats, each bar represents the mean \pm SE. $* * *=p \leq 0.001$ and $* *=p \leq 0.01$ compared to those of control. B12= vitamin B12 and KT= Tromethamine from Ketorolac.

\section{DISCUSSION}

The individual administration of B12 in this study reduced only the mean writhing values of the writhing test. However, researchers reported similar results when they studied the impact of single vitamin B12 supplementation combined with vitamin B1 and B6 administration [11], [31], [32].

In addition, in the writhing test of our study, KT significantly reduced writhing counts and increments of the latency period length. UlugÖl et al. [33] also found an almost identical pattern of results, although it was the impact of writhing counts after subcutaneous administration of Ketorolac (1, 5, and $10 \mathrm{mg} / \mathrm{kg}$ ) was investigated.

In addition, Miranda et al. [34] also recorded a decrease of writhing counts after a single administration of Ketorolac at different doses and routes in mice models. In this study, vit. B12 and KT combination significantly reduced both the study variables for the writhing test in the experimental group.

Medina-Santillan et al. [15] found a similar pattern in outcomes, while they investigated the impact of oral administration of individual Ketorolac $(0.32-10 \mathrm{mg} / \mathrm{kg})$ and combined $(100: 100: 1 \mathrm{mg} / \mathrm{kg})$ in nociceptive pain experiments.

In addition, in the rats treated with a single dose of KT, the decrease in paw oedema volume was statistically significant $(\mathrm{p} \leq 0.01)$. Other researchers also recorded the reduction in paw oedema volume by KT after a single administration of KT at different doses in rat models, showing a similar trend in the findings (25). However, they have investigated the effect of intramuscular administration of individual Ketorolac (24, 80, and $240 \mu \mathrm{M} / \mathrm{kg})$. Furthermore, the combined administration of B12 and KT is more efficient than KT alone in reducing paw oedema volume. Medina-Santillan et al. (2004) (15) have found a similar pattern in their results, while the effects of oral administration of individual Ketorolac $(0.32-10 \mathrm{mg} / \mathrm{kg})$ and combined (100:100:1 $\mathrm{mg} / \mathrm{kg})$ have studied.

The formalin-induced paw oedema test is an effective and easy method of measuring inflammation in animals, in which subcutaneous administration of formalin induces local tissue injury [3], [11]. Unfortunately, the exact mechanism involved in the substantial reduction of inflammation can not be precisely explained in the current research. However, some researchers have indicated that vitamin B12 supplementation can decrease inflammation and reduce TNF-alpha, IL-6, and the formation of some free radicals in inflammatory cells[26], [32], [33].

Some mediators such as TNF-alpha and IL-6 are proinflammatory cytokines, which by increasing the development of more inflammatory cytokines, prostaglandins, free radicals, increase inflammation and inflammatory pain [4], [34], [35]. In addition, free radicals have been suggested to increase inflammation through direct effects on tissue damage, cytokines, and inflammatory oedema formation [36]. Although the precise mechanisms of these effects could not be explicitly clarified in the present research, different suggestions on these aspects were made by various investigators from several countries, which could be the source of our current findings. The antinociceptive activity of vitamin B12 has been suggested to be due to enhanced inhibitory effects of afferent nociceptive neurons at the spinal cord levels, along with decreased thalamic neuron response to nociceptive stimulation [36], [37]. In addition, vitamin B12 stimulation could release endogenous opioids or trigger opioid receptors and the metabolism of GABA, which may reduce the release of neurotransmitters by $\mathrm{Ca} 2+[15]$. Furthermore, GABA could also increase conductance through $\mathrm{K}+$ channels and cause the post-synaptic membrane of the dorsal horn neurons to hyperpolarize, eventually contributing to decreased pain conduction [37], [38].

Again, KT's antinociceptive effect has also been shown to involve activation of the NO-cyclic GMP (cyclic guanosine monophosphate) pathway, accompanied by the opening at the peripheral level of ATP-sensitive $\mathrm{K}+$ channels. In essence, this opening of the channel allows $\mathrm{K}+$ to spread out from the post-synaptic neurons to hyperpolarize it and thus reduce the conduction of pain [4]. Added to this, some researchers have indicated that the anti-inflammatory activity of $\mathrm{KT}$ is mediated by inhibition of COX88 by suppressing PG (prostaglandin) synthesis [13], [37], [38]. In addition, tissue degradation releases inflammatory mediators such as histamine, bradykinin, PGs42, and serotonin. The output of PGs is blocked by KT [37].

\section{CONCLUSION}

It can be inferred from this study that the combined administration of vitamin B12 and KT may be more effective than the individual administration of KT in lowering pain. In addition, the combined administration of vitamin B12 and KT may be more effective than the separate administration of KT in reducing inflammation. Such data will determine the use of vitamin B12 and KT for improved pain control by clinicians and general populations. However, a further experimental study is needed to elucidate the exact component and mechanism responsible for these effects.

\section{LIMITATIONS}

We performed a single-dose test instead of multiple-dose to observe acute antinociceptive effects. We did not complete the chronic antinociceptive and histological change of liver and inflamed paws due to time constraints and funding. 


\section{ACKNOWLEDGEMENT}

We are grateful to Bangabandhu Sheikh Mujib Medical University and Physiology Department, Bangabandhu Sheikh Mujib Medical University.

\section{CONFLICTS OF INTEREST}

The authors declare no conflicts of interest regarding the publication of this paper.

\section{AUTHORS CONTRIBUTION}

- Md. Mizanur Rahman-title concept, study design, data collection, first draft.

- Noorzahan Begum- reanalyzed data, interpreted of data.

- Mahadi Abdur Rouf and Shahriar Masood-data collection, data analysis.

\section{REFERENCES}

[1] Barrot M. Tests and models of nociception and pain in rodents. Neuroscience. https://doi.org/10.1016/j.neuroscience.2011.12.041.

[2] Turk DC, Dworkin RH. What should be the core outcomes in chronic pain clinical trials? Arthritis Res Ther. 62004. p. 151-4. https://arthritisresearch.biomedcentral.com/articles/10.1186/ar1196.

[3] Julius D, Basbaum AI. Molecular mechanisms of nociception. Nature. 2001:413(6852):203-10. https://www.nature.com/articles/35093019.

[4] Woolf CJ. Pain: moving from symptom control toward mechanismspecific pharmacologic management. Ann Intern Med. 2004;140(6):441-51. https://doi.org/10.7326/0003-4819-140-8200404200-00010.

[5] Basbaum AI, Bautista DM, Scherrer G, Julius D. Cellular and Molecular Mechanisms of Pain. Cell. 2009;139(2):267-84. https://doi.org/10.1016/j.cell.2009.09.028.

[6] Loeser JD, Treede RD. The Kyoto protocol of IASP Basic Pain Terminology. Pain. $2008 ; 137(3): 473-7$ https://doi.org/10.1016/j.pain.2008.04.025.

[7] Tajik H, Tamaddonfard E, Hamzeh-Gooshchi N. The effect of curcumin (active substance of turmeric) on the acetic acid-induced visceral nociception in rats. Pak J Biol Sci. 2008;11(2):312-4. https://doi.org/10.3923/pjbs.2008.312.314.

[8] Fereidoni M, Ahmadiani A, Semnanian S, Javan M. An accurate and simple method for measurement of paw edema. J Pharmacol Toxicol Methods. 2000;43(1):11-4. https://doi.org/10.1016/s10568719(00)00089-7.

[9] Gillis JC, Brogden RN. Ketorolac. A reappraisal of its pharmacodynamic and pharmacokinetic properties and therapeutic use in pain management. Drugs. 1997;53(1):139-88. https://doi.org/10.2165/00003495-199753010-00012.

[10] Mathew ST, Devi SG, Kv S. Formulation and evaluation of Ketorolac tromethamine-loaded albumin microspheres for potential intramuscular administration. AAPS PharmSciTech. 2007;8(1):14. https://link.springer.com/article/10.1208/pt0801014.

[11] Franca DS, Souza AL, Almeida KR, Dolabella SS, Martinelli C, Coelho MM. B vitamins induce an antinociceptive effect in the acetic acid and formaldehyde models of nociception in mice. Eur $\mathbf{J}$ Pharmacol. 2001;421(3):157-64. https://doi.org/10.1016/s00142999(01)01038-x.

[12] Reyes-Garcia G, Medina-Santillan R, Teran-Rosales F, CastilloHenkel C, Rodriguez-Silverio J, Torres-Lopez JE, et al. Analgesic effect of B vitamins in formalin-induced inflammatory pain. Proc West Pharmacol Soc. 2001;44:139-40. https://pubmed.ncbi.nlm.nih.gov/11793961/.

[13] Reyes-Garcia G, Castillo-Henkel C, Medina-Santillan R, TeranRosales F, Granados-Soto V. Mechanisms of analgesic action of B vitamins in formalin-induced inflammatory pain. Proc West Pharmacol Soc. 2002;45:144-6. https://pubmed.ncbi.nlm.nih.gov/12434561/.

[14] Rocha-Gonzalez HI, Teran-Rosales F, Reyes-Garcia G, MedinaSantillan R, Granados-Soto V. B vitamins increase the analgesic effect of diclofenac in the rat. Proc West Pharmacol Soc. 2004;47:84-7. https://pubmed.ncbi.nlm.nih.gov/15633620/.
[15] Medina-Santillan R, Reyes-Garcia G, Rocha-Gonzalez HI, GranadosSoto V. B vitamins increase the analgesic effect of ketorolac in the formalin test in the rat. Proc West Pharmacol Soc. 2004;47:95-9. https://pubmed.ncbi.nlm.nih.gov/15633623/.

[16] Padi SS, Naidu PS, Kulkarni SK. Involvement of peripheral prostaglandins in formalin-induced nociceptive behaviours in the orofacial area of rats. Inflammopharmacology. 2006;14(1-2):57-61. https://doi.org/10.1007/s10787-006-1495-7.

[17] Ibrahim MM, Patwardhan A, Gilbraith KB, Moutal A, Yang X, Chew LA, et al. Long-lasting antinociceptive effects of green light in acute and chronic pain in rats. Pain. 2017;158(2):347-60. https://doi.org/10.1097/j.pain.0000000000000767.

[18] Ali T, Javan M, Sonboli A, Semnanian S. Evaluation of the antinociceptive and anti-inflammatory effects of essential oil of Nepeta pogonosperma Jamzad et Assadi in rats. Daru. 202012. p. 48 https://dx.doi.org/10.1186\%2F2008-2231-20-48.

[19] Cormier J, Cone K, Lanpher J, Kinens A, Henderson T, Liaw L, et al Exercise reverses pain-related weight asymmetry and differentially modulates trabecular bone microarchitecture in a rat model of $\begin{array}{llll}\text { osteoarthritis. } & \text { Life } & \text { Sci. } & \text { 2017;180:51-9. }\end{array}$ https://doi.org/10.1016/j.lfs.2017.05.011.

[20] Moallem SA, Hosseinzadeh H, Farahi S. A study of acute and chronic antinociceptive and anti-inflammatory effects of thiamine in mice. Iran Biomed J. 2008;12(3):173-8. https://pubmed.ncbi.nlm.nih.gov/18762821/.

[21] Imtiaz M, Begum N, Ali T, Gomes RR, Saha S, Tasfi RF, et al. Pain \& Inflammation: Effects of short term daily adminstration of Vitamin B12 \& Folic acid in long evans rats. Bangladesh Critical Care Journal 2016;4(1):33-7. https://doi.org/10.3329/bccj.v4i1.27990.

[22] Banode S, Borkar A, Badwaik R. Effect of Ketorolac on opioid induced antinociception in rats. Intl J Med Pharm Sci. 2012;3(3):7-13 https://www.researchgate.net/publication/339841751_EFFECT_OF_ KETOROLAC_ON_OPIOID_INDUCED_ANTINOCICEPTION_IN RATS/stats\#fullTextFileContent.

[23] Kim MJ, Hong BH, Zhang EJ, Ko YK, Lee WH. Antinociceptive effects of intraperitoneal and intrathecal vitamin e in the rat formalin test. Korean J Pain. 2012;25(4):238-44. https://dx.doi.org/10.3344\%2Fkjp.2012.25.4.238.

[24] Tamaddonfard E, Samadi F, Egdami K, editors. The effects of vitamin B12 and diclofenac and their combination on cold and mechanical allodynia in a neuropathic pain model in rats. Veterinary research forum: an international quarterly journal; 2013: Faculty of Veterinary Medicine, Urmia University, Urmia, Iran https://www.ncbi.nlm.nih.gov/pmc/articles/PMC4293892/.

[25] Fukui M, Nakagawa T, Minami M, Satoh M, Kaneko S. Inhibitory role of supraspinal P2X3/P2X2/3 subtypes on nociception in rats. Mol Pain. 2006;2:19. https://dx.doi.org/10.1186\%2F1744-8069-2-19.

[26] Emran TB, Rahman MA, Hosen SZ, Rahman MM, Islam AMT, Chowdhury MAU, et al. Analgesic activity of Leea indica (Burm. f.) Merr. Phytopharmacology. 2012;3(1):150-7. https://www.researchgate.net/publication/267629862_Analgesic_activ ity_of_Leea_indica_Burm_f_Merr_Phytopharmacology.

[27] Abbott FV, Franklin KB, Westbrook RF. The formalin test: scoring properties of the first and second phases of the pain response in rats. Pain. 1995;60(1):91-102. https://doi.org/10.1016/0304 3959(94)00095-v.

[28] Hagiwara H, Kimura F, Mitsushima D, Funabashi T. Formalin-induced nociceptive behavior and c-Fos expression in middle-aged female rats Physiol Behav. 2010;100(2):101-4 https://doi.org/10.1016/j.physbeh.2010.02.004.

[29] Henry JL, Yashpal K, Pitcher GM, Coderre TJ. Physiological evidence that the 'interphase' in the formalin test is due to active inhibition. Pain. 1999;82(1):57-63. https://doi.org/10.1016/s0304-3959(99)00033-0.

[30] Kulisch C, Eckers N, Albrecht D. Method of euthanasia affects amygdala plasticity in horizontal brain slices from mice. J Neurosci Methods.

2011;201(2):340-5. https://doi.org/10.1016/j.jneumeth.2011.08.022.

[31] Bartoszyk G, Wild A. Antinociceptive effects of pyridoxine, thiamine, and cyanocobalamin in rats. Annals of the New York Academy of Sciences. $\quad 1990 ; 585(1): 473-6 . \quad$ https://doi.org/10.1111/j.17496632.1990.tb28079.x.

[32] Hosseinzadeh H, Moallem SA, Moshiri M, Sarnavazi MS, Etemad L. Anti-nociceptive and anti-inflammatory effects of cyanocobalamin (vitamin B12) against acute and chronic pain and inflammation in mice. Arzneimittelforschung. 2012;62(7):324-9. https://doi.org/10.1055/s$0032-1311635$

[33] Ulugöl A, Özyigit F, Yesilyurt Ö, Dogrul A. The additive antinociceptive interaction between WIN 55,212-2, a cannabinoid agonist, and Ketorolac. Anesthesia \& Analgesia. 2006;102(2):443-7. https://doi.org/10.1213/01.ane.0000194587.94260.1d. 
[34] Miranda HF, Sierralta F, Pinardi G. Previous administration of indomethacin or naloxone did not influence ketorolac antinociception in mice. Anesthesia and analgesia. 1993;77(4):750-3 https://doi.org/10.1213/00000539-199310000-00016.

[35] Fu QG, Carstens E, Stelzer B, Zimmermann M. B vitamins suppress spinal dorsal horn nociceptive neurons in the cat. Neurosci Lett. 1988;95(1-3):192-7. https://doi.org/10.1016/0304-3940(88)90655-6.

[36] Jurna I, Carlsson KH, Komen W, Bonke D. Acute effects of vitamin B6 and fixed combinations of vitamin B1, B6 and B12 on nociceptive activity evoked in the rat thalamus: dose-response relationship and combinations with morphine and paracetamol. Klin Wochenschr. 1990;68(2):129-35. https://doi.org/10.1007/bf01646861.

[37] Bardin L. The complex role of serotonin and 5-HT receptors in chronic pain. Behavioural pharmacology. 2011;22(5 and 6):390-404 https://doi.org/10.1097/fbp.0b013e328349aae4.

[38] Lazaro-Ibanez GG, Torres-Lopez JE, Granados-Soto V. Participation of the nitric oxide-cyclic GMP-ATP-sensitive $\mathrm{K}(+)$ channel pathway in the antinociceptive action of Ketorolac. Eur J Pharmacol. 2001;426(12):39-44. https://doi.org/10.1016/s0014-2999(01)01206-7. 